\title{
Electrochemical Characteristics of Phthaloyl Chitosan Based Gel Polymer Electrolyte for Dye Sensitized Solar Cell Application
}

\author{
A.M. Zulkifli ${ }^{1}$, N.I.A.M. Said ${ }^{1}$, Shujahadeen B. Aziz, ${ }^{2,3 *}$,Shameer Hisham ${ }^{4}$, Shahan.Shah ${ }^{1}$, Amnani Abu \\ Bakar $^{5}$, Z.H.Z. Abidin ${ }^{1}$, H.A. Tajuddin ${ }^{4}$, L. Sulaiman ${ }^{1}$, M. A. Brza ${ }^{6,2}$, Jihad M. Hadi, , Shakhawan Al- \\ Zangana $^{9}$
}

${ }^{1}$ Visible Spectrum Laboratory, Centre for Ionics University of Malaya, Department of Physics, Faculty of Science, University of Malaya, 50603 Kuala Lumpur, Malaysia.

${ }^{2}$ Advanced Polymeric Materials Research Lab., Department of Physics, College of Science, University of Sulaimani, Qlyasan Street, Sulaimani, Kurdistan Regional Government-Iraq.

${ }^{3}$ Department of Civil Engineering, College of Engineering, Komar University for Science and

Technology, Sulaimani, Kurdistan Regional Government-Iraq.

${ }^{4}$ Organic Research Laboratory, Department of Chemistry, Faculty of Science, University of Malaya,

50603 Kuala Lumpur, Malaysia.

${ }^{5}$ Department of Civil Engineering Technology, Faculty of Engineering Technology, University Tun Hussein Onn Malaysia, Edu Hub Pagoh, 84600 Pancor Johor.

${ }^{6}$ Manufacturing and Materials Engineering Department, Faculty of Engineering, International Islamic

University of Malaysia, Kuala Lumpur 50603, Gombak, Malaysia.

${ }^{7}$ Kurdistan Technical Institute,Sulaimani, Kurdistan Regional Government-Iraq

${ }^{8}$ College of Engineering, Tishk International University, Sulaimani, Kurdistan Regional GovernmentIraq

${ }^{9}$ Department of Physics, College of Education, University of Garmian, Kalar, 46021, Iraq

*E-mail: shujahadeenaziz@gmail.com; hairul@um.edu.my

doi: $10.20964 / 2020.08 .86$

Received: 7 April 2020/ Accepted: 9 June 2020 / Published: 10 July 2020

In this project, a set of gel polymer electrolytes (GPEs) was fabricated using Phthaloyl Chitosan $(\mathrm{PhCh})$ as a host polymer, ethyl carbonate (EC) like a plasticizer, potassium selenocyanate (KSeCN) as salt, and selenocyanogen as redox mediators to fabricate the dye-sensitized solar cells (DSSCs). The electrical properties of prepared GPE systems have been characterized by dielectric permittivity and electrical impedance spectroscopy (EIS). Through the impedance spectra, the ionic conductivity of the GPE systems was evaluated at room temperature. It was observed that the ionic conductivity of PhChbased GPE was increased with the increase of salt amount, and the uppermost ionic conductivity is $4.76 \times 10^{-2} \mathrm{~S} \mathrm{Cm}^{-1}$ was obtained from the maximum content of $\mathrm{KSeCN}$ : $(\mathrm{SeCN})_{2}$ added salt. On the other hand, the increases of dielectric parameters $\left(\varepsilon^{\prime}, \varepsilon^{\prime \prime}\right)$ indicated that the rise of the dielectric polarization in GPE systems. The films were used to dye-sensitized solar cells (DSSC) to perceive the 
GPEs usefulness. For GPEs including KSeCN, the DSSC ( $1 \%$ ) efficiency for the N3 dyes obtained was $2.28 \%$ with $J_{s c}\left(6.19 \mathrm{~mA} / \mathrm{cm}^{2}\right), V_{\mathrm{oc}}(0.61 \mathrm{~V})$, as well as fill factor $(0.60)$.

Keywords: phthaloyl chitosan, gel polymer electrolyte, dielectric constant, ionic conductivity, dyesensitized solar cell (DSSC)

\section{$\underline{\text { FULL TEXT }}$}

(C) 2020 The Authors. Published by ESG (www.electrochemsci.org). This article is an open access article distributed under the terms and conditions of the Creative Commons Attribution license (http://creativecommons.org/licenses/by/4.0/). 